\title{
Infrared Spectroscopic Study Dihydroquercetin and its New Substances with Benzoyl Chloride
}

\author{
A. K. Boshkayeva ${ }^{1}$, R. A. Omarova ${ }^{1}$, K. B. Zharimbetov ${ }^{2}$, G. S. Ibadullayeva ${ }^{3}$, E. M. Bissenbaev ${ }^{3}$, \\ K. K. Zhaldybaev ${ }^{4}$, M. K. Iskakova ${ }^{5}$, Samir Anis Ross ${ }^{6}$, A. S. Kozhamzharova ${ }^{7}$ \\ ${ }^{1}$ Module "Pharmacist-analyst", Institute of Pharmacy, Asfendiyarov Kazakh National Medical University, Almaty, The Republic of \\ Kazakhstan \\ ${ }^{2}$ Module "Pharmacist-manager", Institute of Pharmacy, Asfendiyarov Kazakh National Medical University, Almaty, The Republic of \\ Kazakhstan \\ ${ }^{3}$ Module "Pharmacist-technologist", Institute of Pharmacy, Asfendiyarov Kazakh National Medical University, Almaty, The Republic of \\ Kazakhstan \\ ${ }^{4}$ Joint Course of pharmacology and pharmacy, Kazakh-Russian Medical University, Almaty, The Republic of Kazakhstan \\ ${ }^{5}$ Department of Internship of Dentistry, Institute of Stomatology, Asfendiyarov Kazakh National Medical University, Almaty, The Republic \\ of Kazakhstan \\ ${ }^{6}$ National Scientific Center for Natural Products, University of Mississippi, Oxford, The United States \\ ${ }^{7}$ Module "Pharmacist-toxicologist", Institute of Pharmacy, Asfendiyarov Kazakh National Medical University, Almaty, The Republic of \\ Kazakhstan
}

\section{Email address:}

kenes65@mail.ru (A. K. Boshkayeva), omarova-r@list.ru (R. A. Omarova), arujan-d@mail.ru (G. S. Ibadullayeva), bissenbayev1941@mail.ru (E. M. Bissenbaev), marya_iskakova@mail.ru (M. K. Iskakova), sross@olemiss.edu (Samir Anis Ross), chimtoks@mail.ru (A. S. Kozhamzharova)

\section{To cite this article:}

A. K. Boshkayeva, R. A. Omarova, K. B. Zharimbetov, G. S. Ibadullayeva, E. M. Bissenbaev, K. K. Zhaldybaev, M. K. Iskakova, Samir Anis Ross, A. S. Kozhamzharova. Infrared Spectroscopic Study Dihydroquercetin and its New Substances with Benzoyl Chloride. Clinical Medicine Research. Special Issue: Development of Drugs: Computer Simulation, Chemical Synthesis and Clinical Trials.

Vol. 5, No. 2-2, 2016, pp. 1-7. doi: 10.11648/j.cmr.s.2016050202.11

Received: December 23, 2015; Accepted: December 25, 2015; Published: June 18, 2016

\begin{abstract}
The study acylation reactions of dihydroquercetin apart from scientific interest has practical value. As a result of the reactions will form new organic compounds which may possess potential antioxidant, anti-inflammatory and cytotoxic activity [1]. Within this research studying of processes of acylation of a dihydroquercetin with use of benzoyl chloride and definition of chemical structure of new medicinal substances, as homogeneous samples of high degree of purity was the important and interesting point. One of the promising methods of studying the structure of drug substances is the method of IR spectroscopy. The method gives the chance to make an objective assessment of authenticity that allows to use actively it in the pharmaceutical analysis of many unknown connections [2-4]. It predetermined conduct of the compulsory registration of IR spectra for the original dihydroquercetin and synthesized on its basis of new substances with benzoyl chloride.
\end{abstract}

Keywords: Dihydroquercetin, benzoyl chloride, identification, infrared spectroscopy, the State Pharmacopoeia of Republic Kazakhstan, synthesis

\section{Introduction}

It should be noted that dihydroquercetin other than useful properties has a number of features some of which hinder its widespread use for practical purposes, in particular, it has poor water solubility.

Taking into account the told there was a need of studying of its chemical transformations including connected with giving to a molecule of bigger polarity. Its acylation of acid chloride of carbonic acids can become one of the directions of transformations of a dihydroquercetin. 
Introduction to structure of the flavonoids presented dihydroquercetin, additional the pharmacophore groups is undoubtedly an actual task. As an acylating reagent was chosen acid chloride of benzoic acid.

\section{The Experimental Part}

The identification of new substances obtained by IR spectroscopy was performed according to the State Pharmacopoeia of the Republic of Kazakhstan (SPh RK) 2.2.24 on the spectrometer «Shimadzu» by Fourier transformer in the absorption region $4000-400 \mathrm{~cm}^{-1}$. To record the IR spectra were used the samples in the form of disks with $\mathrm{KBr}$, made by the method specified in the State Pharmacopoeia of the Republic of Kazakhstan ( $\mathrm{SPh} \mathrm{RK}$ ), Issue $1[2,5]$ : of from 1 to $2 \mathrm{mg}$ of a substance was triturated with $300-400 \mathrm{mg}$ of dried and finely ground potassium bromide $\mathrm{P}$ to form a homogeneous mixture. From the mixture by pressing at a pressure of about $800 \mathrm{MPa}$ was obtained in a 10-15 mm diameter disks. To record the spectra were used only transparent discs.

\section{Discussion of Results}

The results of infrared spectroscopic studies synthesized in different molar parities of the compounds are presented in Table 1 and Figures 1, 2, 3, 4, 5.

The reference to the fundamental vibrational frequency are made on the basis of literary data of [3, 6-10] and known features of chemical structure of a dihydroquercetin and benzoyl chloride.

Chemical structure of dihydroquercetin (1), a geometric model of the molecular system of dihydroquercetin's (1 a), benzoyl chloride (2) and a geometric model of the molecular system of benzoyl chloride's ( 2 a) have the following form:<smiles>O=C1c2c(O)cc(O)cc2OC(c2ccc(O)c(O)c2)C1O</smiles>

(1)

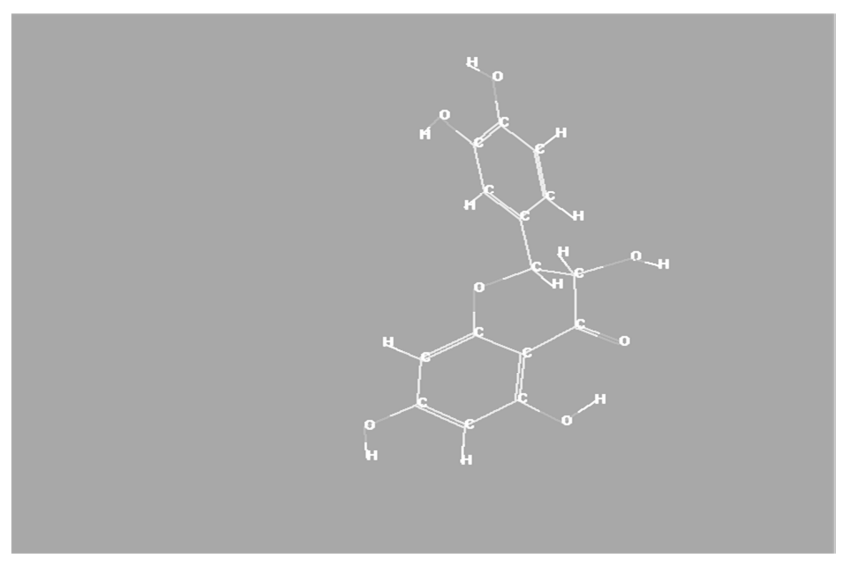

(1a)<smiles>O=C(Cl)c1ccccc1</smiles> 


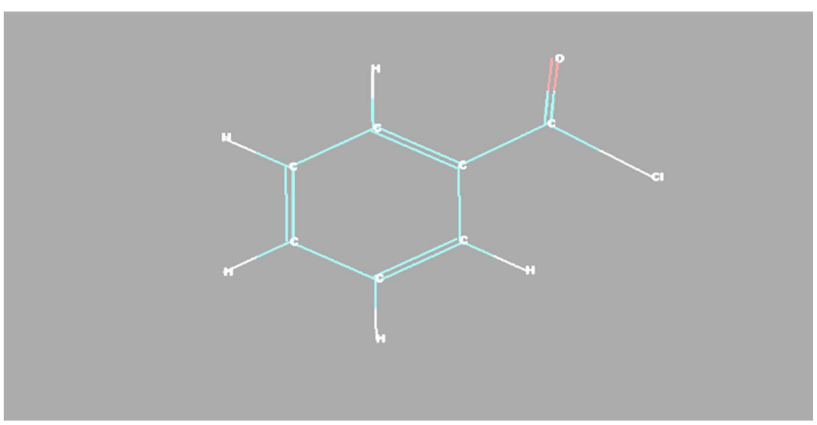

(2a)

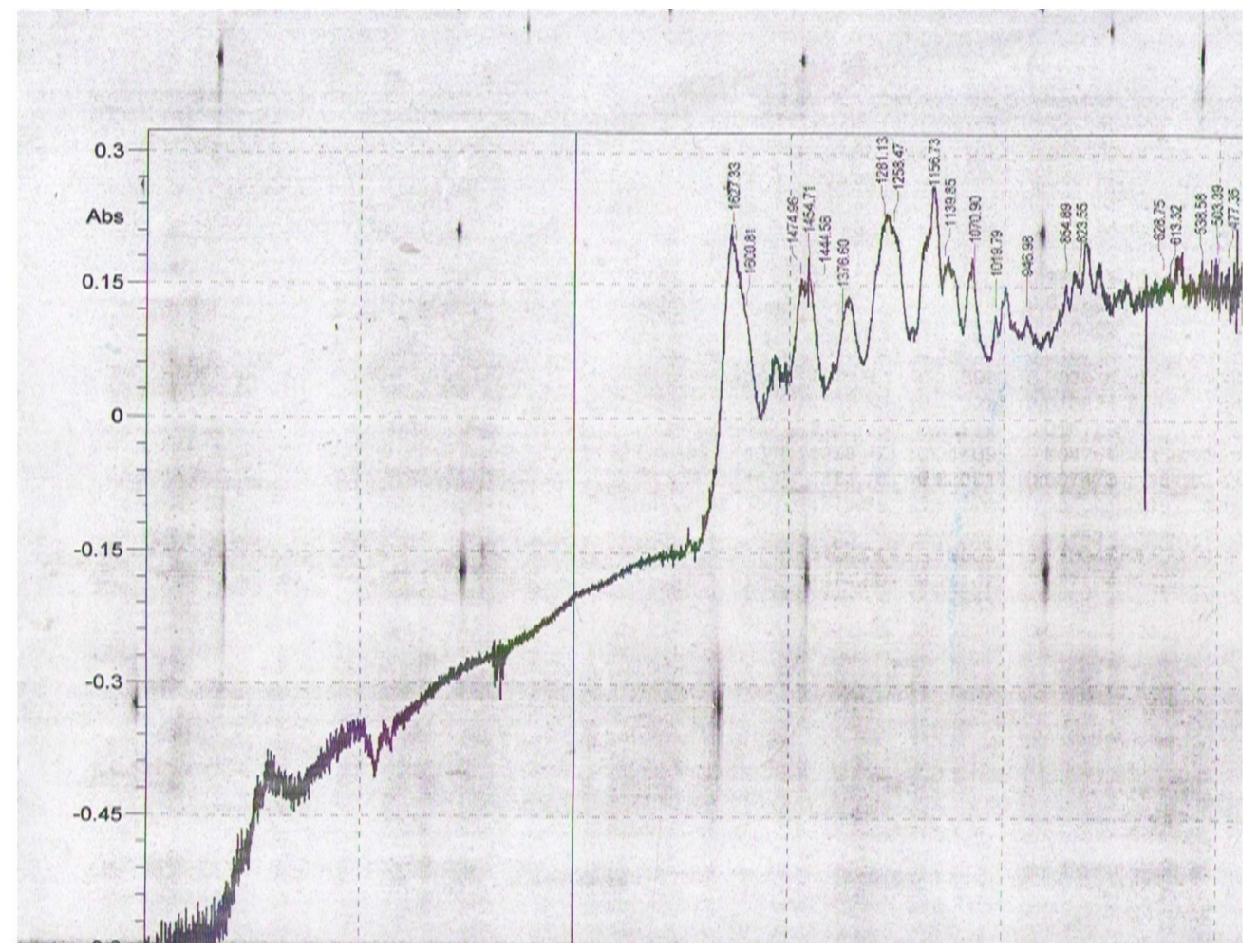

Figure 1. IR spectrum of substance Dihydroquercetin-Benzoyl chloride 1:1.

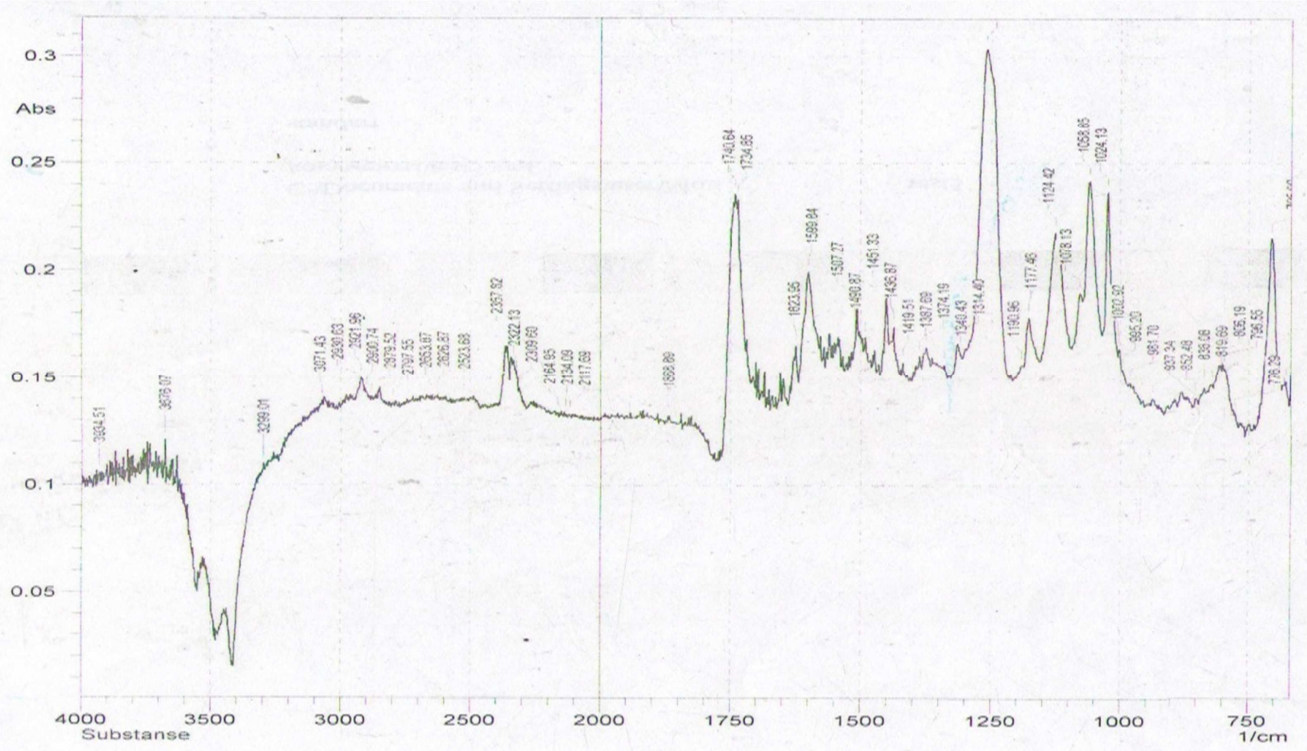

Figure 2. IR spectrum of substance Dihydroquercetin-Benzoyl chloride 1:2. 


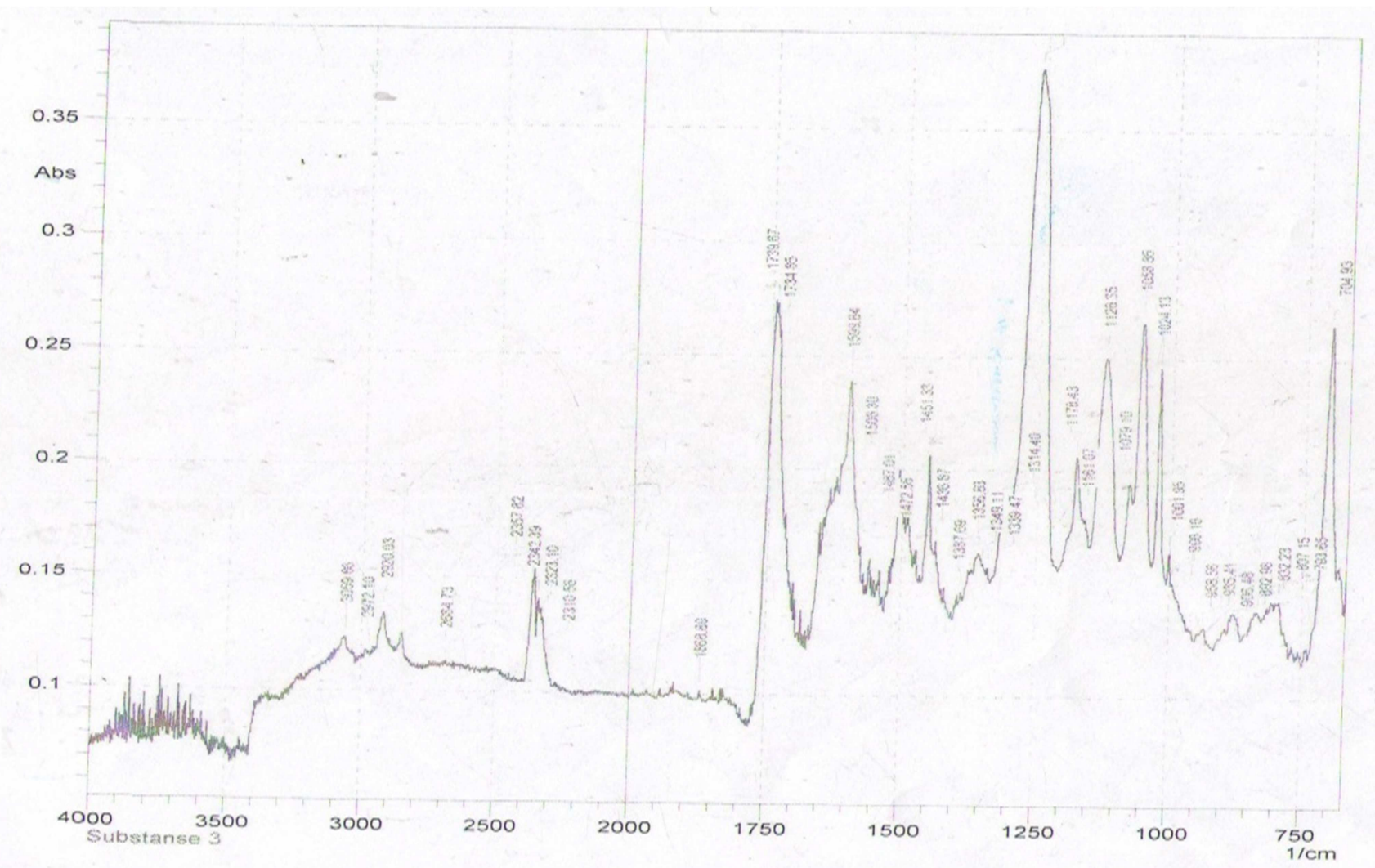

Figure 3. IR spectrum of substance Dihydroquercetin-Benzoyl chloride 1:3.

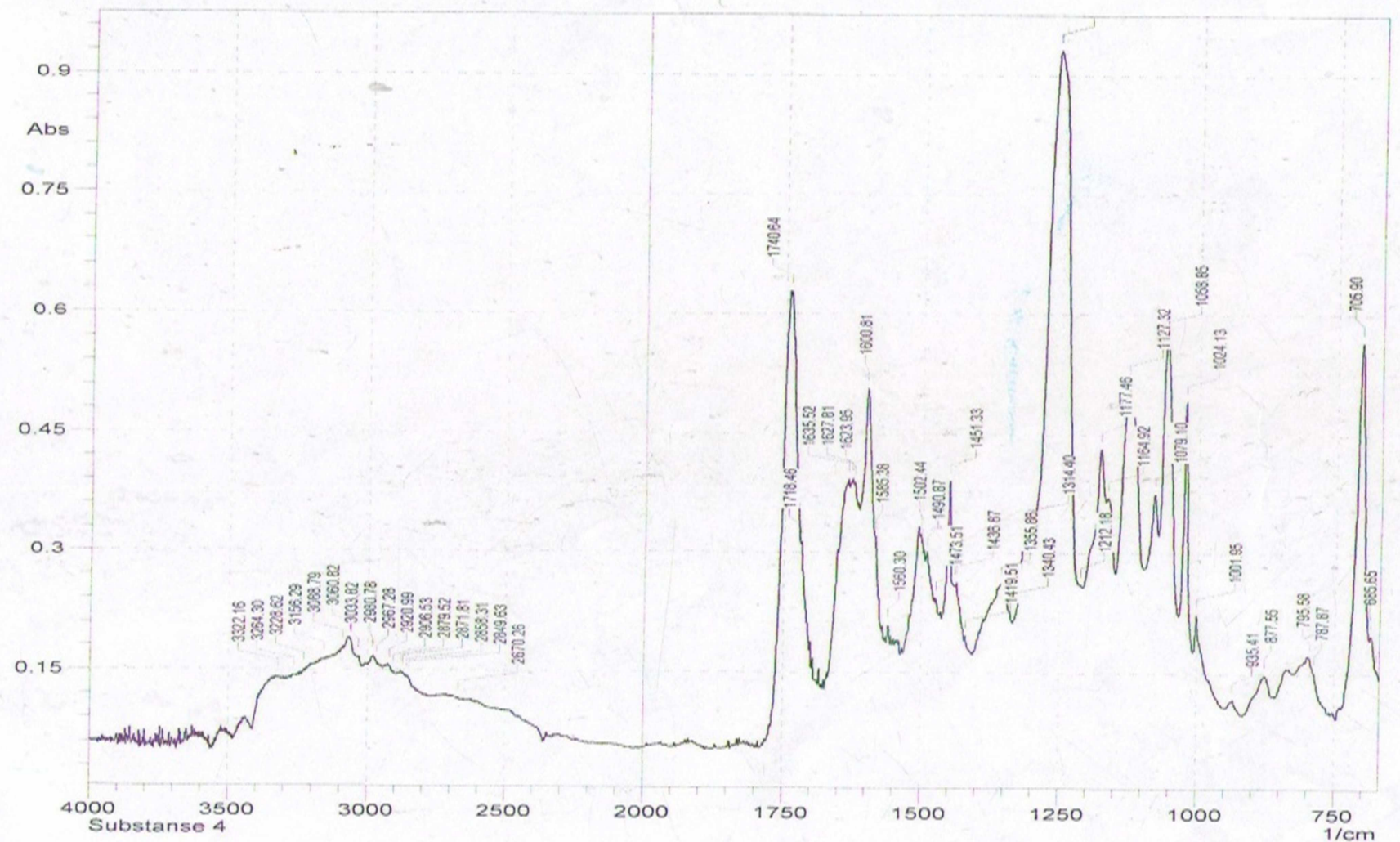

Figure 4. IR spectrum of substance Dihydroquercetin-Benzoyl chloride 1:4. 


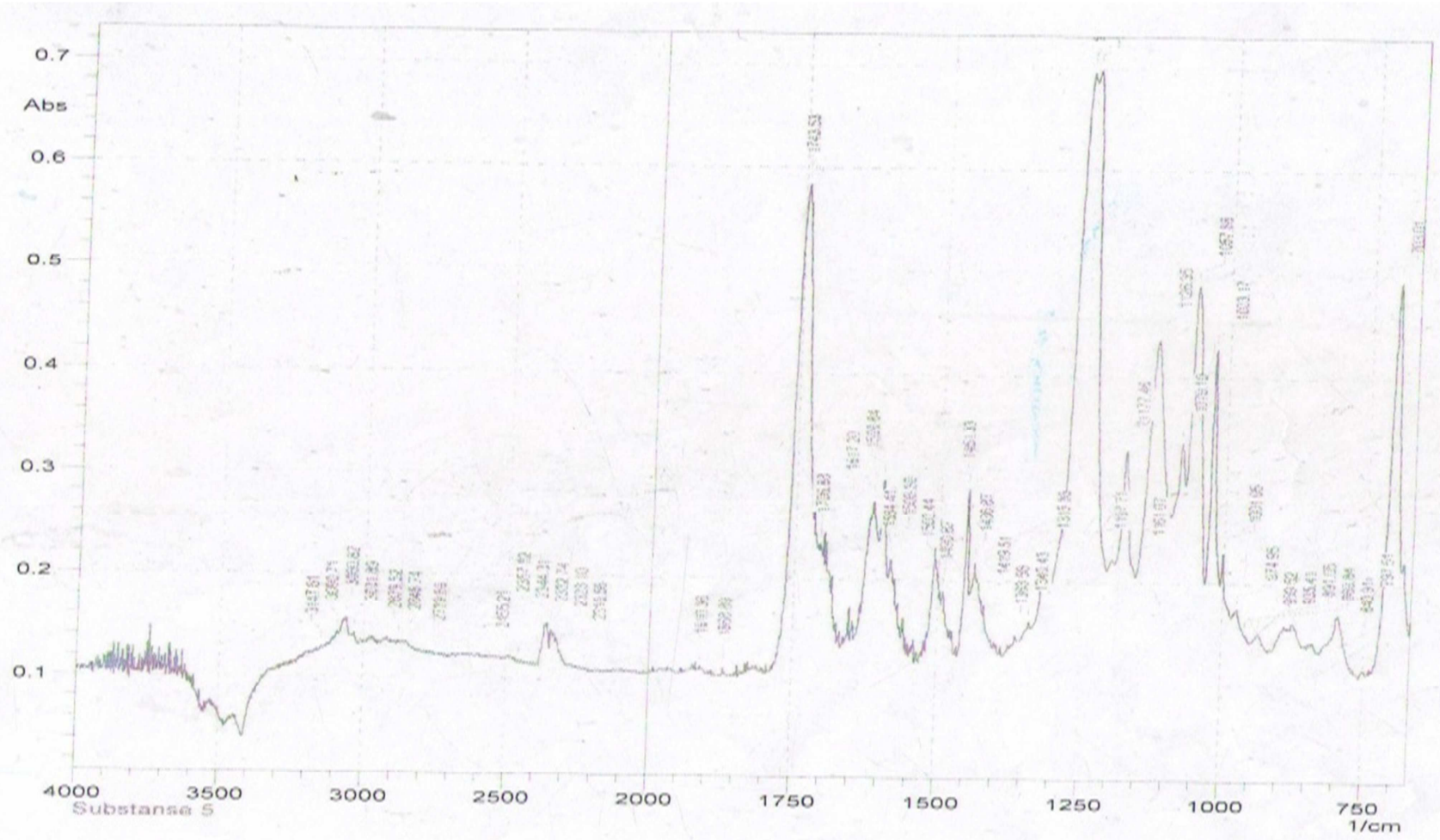

Figure 5. IR spectrum of substance Dihydroquercetin-Benzoyl chloride 1:5.

From a consideration these spectra it should be noted that the main attention should be given in the vibrational frequency spectra of such functional groups as hydroxyl, carbonyl, a phenyl radical, and also take into account the vibrational frequency of $\mathrm{C}-\mathrm{C}, \mathrm{C}=\mathrm{C}$ and $\mathrm{C}-\mathrm{Cl}$ bonds. Therefore, in the following table are referring to the fundamental vibrational frequencies of these functional groups and bonds.

Table 1. Main vibrational frequencies in the IR spectra dihydroquercetin and new substances with a benzoyl chloride, $\mathrm{cm}^{-1}$.

\begin{tabular}{|c|c|c|c|c|c|c|}
\hline $\begin{array}{l}\text { The } \\
\text { assignment of } \\
\text { absorption } \\
\text { bands }\end{array}$ & $\begin{array}{l}\text { Dihydroquerceti } \\
\mathrm{n}\end{array}$ & $\begin{array}{l}\text { Dihydroquercetin- } \\
\text { benzoyl chloride } \\
(1: 1)\end{array}$ & $\begin{array}{l}\text { Dihydroquercetin- } \\
\text { benzoyl chloride } \\
(1: 2)\end{array}$ & $\begin{array}{l}\text { Dihydroquercetin- } \\
\text { benzoyl chloride } \\
\text { (1:3) }\end{array}$ & $\begin{array}{l}\text { Dihydroquercetin } \\
\text {-benzoyl chloride } \\
(1: 4)\end{array}$ & $\begin{array}{l}\text { Dihydroquercetin- } \\
\text { benzoyl chloride } \\
\text { (1:5) }\end{array}$ \\
\hline$v^{\text {as }}(\mathrm{OH})$ & $\begin{array}{l}3437 \mathrm{~s} . \\
3428 \mathrm{~s} .\end{array}$ & noises & noises & noises & - & - \\
\hline$v^{\mathrm{s}}(\mathrm{OH})$ & $\begin{array}{l}3403 \mathrm{~m} . \\
3395 \mathrm{~m} .\end{array}$ & - & - & - & - & - \\
\hline Adsorpt. $\mathrm{CO}_{2}$ & - & - & $\begin{array}{l}2358 \mathrm{~m} . \\
2322 \mathrm{~m} .\end{array}$ & $\begin{array}{l}2353 \mathrm{~m} . \\
2323 \mathrm{~m} .\end{array}$ & - & $\begin{array}{l}2357 \mathrm{w} . \\
2344 \mathrm{w} . \\
2332 \mathrm{w} .\end{array}$ \\
\hline $\begin{array}{l}v^{\text {as }}(\mathrm{C}=\mathrm{O}) \text { in } \\
\text { undissociated } \\
\text { carbonyl group }\end{array}$ & - & - & $\begin{array}{l}1740 \text { v.s. } \\
1735 \text { s. }\end{array}$ & $\begin{array}{l}1740 \text { v.s. } \\
1735 \text { s. }\end{array}$ & 1741 v.s. & 1744 v.s. \\
\hline $\begin{array}{l}v^{\text {as }}(\mathrm{C}=\mathrm{O}) \text { in } \\
\text { undissociated } \\
\text { carbonyl group }\end{array}$ & - & - & - & - & $1718 \mathrm{~m}$ & $1707 \mathrm{~m}$. \\
\hline $\begin{array}{l}v^{\text {as }}(\mathrm{C}=\mathrm{C})+\delta \\
(\mathrm{COH})\end{array}$ & $\begin{array}{l}- \\
1611 \text { v.s. } \\
1605 \text { v.s. } \\
1602 \text { shoulder } \\
1596 \text { shoulder }\end{array}$ & 1600 shoulder & $1623 \mathrm{w}$. & 1600 v.s. & $\begin{array}{l}1635 \mathrm{~m} . \\
1623 \mathrm{~m} . \\
1601 \mathrm{~s} .\end{array}$ & $1617 \mathrm{w}$. \\
\hline$v^{\text {as }}(\mathrm{C}=\mathrm{C})$ & $1532 \mathrm{~m}$. & - & - & $1506 \mathrm{~s}$. & $1502 \mathrm{~m}$. & $\begin{array}{l}1506 \mathrm{~m} . \\
1502 \mathrm{~m} .\end{array}$ \\
\hline$\delta^{\text {as }}\left(\mathrm{CH}_{2}\right)$ & $\begin{array}{l}- \\
1455 \mathrm{~s} . \\
1446 \mathrm{w} .\end{array}$ & $\begin{array}{l}1475 \text { s. } \\
1455 \text { v.s. }\end{array}$ & $\begin{array}{l}1491 \mathrm{~m} . \\
1452 \mathrm{~m} . \\
1437 \mathrm{w} .\end{array}$ & $\begin{array}{l}1487 \mathrm{~m} . \\
1451 \mathrm{~m} . \\
1437 \mathrm{w} .\end{array}$ & $\begin{array}{l}1491 \mathrm{~m} . \\
1473 \mathrm{~m} . \\
1437 \mathrm{~s} . \\
1420 \mathrm{~m} .\end{array}$ & $\begin{array}{l}1491 \mathrm{w} . \\
1451 \mathrm{~m} . \\
1437 \mathrm{w} . \\
1420 \mathrm{w} .\end{array}$ \\
\hline
\end{tabular}




\begin{tabular}{|c|c|c|c|c|c|c|}
\hline $\begin{array}{l}\text { The } \\
\text { assignment of } \\
\text { absorption } \\
\text { bands }\end{array}$ & $\begin{array}{l}\text { Dihydroquerceti } \\
\text { n }\end{array}$ & $\begin{array}{l}\text { Dihydroquercetin- } \\
\text { benzoyl chloride } \\
(1: 1)\end{array}$ & $\begin{array}{l}\text { Dihydroquercetin- } \\
\text { benzoyl chloride } \\
(1: 2)\end{array}$ & $\begin{array}{l}\text { Dihydroquercetin- } \\
\text { benzoyl chloride } \\
(1: 3)\end{array}$ & $\begin{array}{l}\text { Dihydroquercetin } \\
\text {-benzoyl chloride } \\
(1: 4)\end{array}$ & $\begin{array}{l}\text { Dihydroquercetin- } \\
\text { benzoyl chloride } \\
\text { (1:5) }\end{array}$ \\
\hline$\delta^{\mathrm{s}}\left(\mathrm{CH}_{2}\right)$ & $\begin{array}{l}1369 \mathrm{~s} . \\
1364 \mathrm{w} .\end{array}$ & $1377 \mathrm{~s}$. & $\begin{array}{l}1388 \mathrm{w} . \\
1374 \mathrm{w} . \\
1340 \mathrm{w} . \\
1314 \mathrm{w} .\end{array}$ & $\begin{array}{l}1387 \mathrm{w} . \\
1349 \mathrm{w} . \\
1339 \mathrm{w} . \\
1314 \mathrm{w} .\end{array}$ & $\begin{array}{l}- \\
1356 \mathrm{~m} . \\
1340 \mathrm{~m} . \\
1314 \mathrm{~s} .\end{array}$ & $\begin{array}{l}1363 \mathrm{w} . \\
1340 \mathrm{w} . \\
1315 \mathrm{w} .\end{array}$ \\
\hline & 1272 v.s. & - & - & - & - & - \\
\hline $\begin{array}{l}v^{\text {as }}(\mathrm{C}-\mathrm{C})+v \\
(\mathrm{C}-\mathrm{O})\end{array}$ & $\begin{array}{l}1268 \mathrm{~m} . \\
1249 \mathrm{~m} . \\
1210 \mathrm{~m} .\end{array}$ & 1261 v.s. & 1259 v.s. & 1258 v.s. & $\begin{array}{l}1258 \text { v.s. } \\
1212 \mathrm{~m} .\end{array}$ & $\begin{array}{l}1256 \text { v.s. } \\
1245 \text { v.s. }\end{array}$ \\
\hline$v^{\mathrm{s}}(\mathrm{C}-\mathrm{C})+v(\mathrm{C}-$ & $\begin{array}{l}1191 \mathrm{~m} . \\
1166 \text { v.s. }\end{array}$ & - & $\begin{array}{l}1191 \mathrm{~m} . \\
1177 \mathrm{~m} .\end{array}$ & $\begin{array}{l}1178 \mathrm{~m} . \\
1161 \mathrm{~m} .\end{array}$ & $\begin{array}{l}1177 \mathrm{~s} . \\
1164 \mathrm{~s} .\end{array}$ & $\begin{array}{l}1198 \mathrm{~m} . \\
1177 \mathrm{~m} .\end{array}$ \\
\hline O) & $\begin{array}{l}1161 \text { v.s. } \\
1140 \text { s. }\end{array}$ & $\begin{array}{l}1157 \text { v.s. } \\
1140 \mathrm{~s} .\end{array}$ & $\begin{array}{l}- \\
1124 \mathrm{~s} .\end{array}$ & - & $\begin{array}{l}- \\
1127 \text { o.c. }\end{array}$ & $\begin{array}{l}1161 \mathrm{~m} . \\
1126 \mathrm{~s} .\end{array}$ \\
\hline$\delta^{\text {as }}(\mathrm{CCH})$ & $\begin{array}{l}1074 \mathrm{~s} . \\
- \\
1020 \mathrm{~m} .\end{array}$ & $\begin{array}{l}1071 \mathrm{~s} . \\
- \\
1020 \mathrm{~s} .\end{array}$ & $\begin{array}{l}1078 \mathrm{~m} . \\
1059 \mathrm{~s} . \\
1024 \mathrm{~s}\end{array}$ & $\begin{array}{l}1079 \mathrm{~m} . \\
1059 \mathrm{~s} . \\
1024 \mathrm{~s} .\end{array}$ & $\begin{array}{l}1079 \text { s. } \\
1058 \text { s. } \\
1024 \text { v.s. }\end{array}$ & $\begin{array}{l}1079 \mathrm{~s} \\
1057 \mathrm{~s} . \\
1023 \mathrm{~s} .\end{array}$ \\
\hline$\delta^{\mathrm{s}}(\mathrm{CCH})$ & $\begin{array}{l}1004 \mathrm{~m} . \\
999 \mathrm{~m} .\end{array}$ & - & $\begin{array}{l}1003 \mathrm{w} . \\
995 \mathrm{w} . \\
947 \mathrm{~m} .\end{array}$ & $\begin{array}{l}1002 \mathrm{w} . \\
996 \mathrm{w} .\end{array}$ & $\begin{array}{l}1002 \mathrm{s.} \\
935 \mathrm{w} .\end{array}$ & $\begin{array}{l}1002 \mathrm{~m} . \\
975 \mathrm{~m} . \\
935 \mathrm{w} .\end{array}$ \\
\hline$\delta^{\text {as }}(\mathrm{C}-\mathrm{C}-\mathrm{O})$ & $\begin{array}{l}854 \mathrm{w} . \\
809 \mathrm{w} .\end{array}$ & $855 \mathrm{~m}$. & $\begin{array}{l}853 \mathrm{w} . \\
836 \mathrm{w} . \\
806 \mathrm{~m} .\end{array}$ & $\begin{array}{l}832 \text { w. } \\
807 \text { w. }\end{array}$ & 878 w. & $\begin{array}{l}891 \mathrm{w} . \\
841 \mathrm{w} .\end{array}$ \\
\hline$\delta^{\mathrm{s}}(\mathrm{C}-\mathrm{C}-\mathrm{O})$ & $778 \mathrm{w}$. & noises & $\begin{array}{l}776 \mathrm{w} . \\
705 \mathrm{w} .\end{array}$ & $\begin{array}{l}794 \mathrm{w} . \\
705 \mathrm{~s} .\end{array}$ & $\begin{array}{l}795 \mathrm{w} . \\
788 \mathrm{w} . \\
706 \text { v.s. }\end{array}$ & $\begin{array}{l}798 \mathrm{w} . \\
703 \mathrm{~s} .\end{array}$ \\
\hline $\begin{array}{l}\text { The pendular } \\
\text { deformation } \\
\mathrm{CCH} \text { and } \\
\text { torsional } \\
\text { deformation } \\
\mathrm{COH}\end{array}$ & $406 \mathrm{w}$. & - & $679 \mathrm{w}$. & $680 \mathrm{w}$. & $\begin{array}{l}685 \mathrm{~m} . \\
675 \mathrm{w} .\end{array}$ & $684 \mathrm{~m}$. \\
\hline
\end{tabular}

In the spectrum of the molecule dihydroquercetin absorption bands are observed with high intensity at 3437 and $3428 \mathrm{~cm}^{-1}$, which are assigned to the antisymmetric stretching vibrations of $\mathrm{OH}$ hydroxy group present in the molecule of the original substance. Respectively the absorption bands caused by vibrations of these groups include the bands at 3403 and $3395 \mathrm{~cm}^{-1}$, the intensity of which is somewhat lower. Proceeding from small structure and the provision of the considered strips, it is possible to note that hydroxyl groups in the studied molecules are involved in hydrogen communications as the free not associated hydroxyl group would have a narrow strip of absorption in the field of 3600-3580 $\mathrm{cm}^{-1}$. Deformation scissors fluctuations the $\mathrm{COH}$-groups are shown in more lowfrequency area $\left(-1600 \mathrm{~cm}^{-1}\right)$.

In ranges of new substances with various ratio of benzoyl chloride in them intensity of strips in the field of 3500-3200 $\mathrm{cm}^{-1}$ becomes much lower and in the majority of ranges of these connections absorption is shown generally at the level of noise. This allows to conclude that in the new substances hydroxyl groups as independent structural units do not exist; they are mainly involved in numerous intra and intermolecular interactions.

In the spectra some of new substances is observed absorption bands in the region of $2400-2300 \mathrm{~cm}^{-1}$ medium or low intensity. They are caused by vibrations antisymmetric linear physically adsorbed $\mathrm{CO}_{2}$ molecules.
Despite the presence in the chemical structure dihydroquercetin carbonyl group absorption band caused by its vibrations, absent in its spectrum. This indicates that the initial dihydroquercetin, which is located in associated state and the carbonyl group which is present there in, participates in intramolecular bonds. In the spectra of the compounds dihydroquercetin with benzoyl chloride, since the ratio of components of 1:2 are observed sufficiently high intensity narrow absorption band in the region of $1700-1750 \mathrm{~cm}^{-1}$, and are caused by anti-symmetric stretching vibrations of $\mathrm{C}=\mathrm{O}$ in carboxyl groups, benzoyl chloride, which is an acid chloride of benzoic acid.

It should be noted that the number of absorption bands in this region with an increasing number molecules of benzoyl chloride in its substance dihydroquercetin gradually increases. All this testifies to the free carbonyl group and the gradual increase of its freedom.

In the spectra of the initial dihydroquercetin and its compounds with benzoyl chloride are observed high intensity and highly structured absorption bands in the region 1500$1640 \mathrm{~cm}^{-1}$. They are caused by the stretching vibrations of the $\mathrm{C}=\mathrm{C}$ bonds in the aromatic rings dihydroquercetin and benzoyl chloride. Along with a stretching $\mathrm{C}=\mathrm{C}$ bond these vibrations are not strictly stretching because they contribute changing of bond angles $\mathrm{C}-\mathrm{C}=\mathrm{O}$. Identified the following consistent pattern: adherence to the molecule dihydroquercetin the benzoyl chloride leads to decrease in 
the number of bands in this area, which is most likely connected, with decreasing of degrees of freedom of the benzene ring by forming a new donor-acceptor bonds between the interacting components.

Asymmetric and symmetric deformational vibrations of $\mathrm{CCH}$ and $\mathrm{CH}_{2}$ groups in benzene rings investigated spectral structures are manifested in the $1300-1400 \mathrm{~cm}^{-1}$. Bands corresponding to these oscillations, sufficiently structured and have high strength. The number of bands in considered area does not depend on degree of association dihydroquercetin with benzoyl chloride.

Suffice highly structured band in the spectra of all the compounds are observed in the absorption region 1100-1270 $\mathrm{cm}^{-1}$. Their intensity is also quite high. They are caused by anti- and symmetric stretching vibrations of C-C- and C-O bonds of the core parts of the investigated compounds.

Blended platforms Scissor deformational vibrations of $\mathrm{CCH}$ groups and $\mathrm{CCO}$ are manifested in the spectra of all the compounds in the $700-1100 \mathrm{~cm}^{-1}$, and there are the pendular and torsional deformations of $\mathrm{CCH}$ - and $\mathrm{COH}$ groups in the region below $700 \mathrm{~cm}^{-1}$.

\section{Conclusions}

1. Analysis of IR spectra of the dihydroquercetin and the new compounds with benzoyl chloride, which was prepared in various ratios, shows that they have a certain vibrational structure, indicating the presence of basic functional groups typical initial components.

2. Changes in the positions the individual absorption bands are directly related to the donor-acceptor interaction between dihydroquercetin and benzoyl chloride.

\section{Reference}

[1] Boshkayeva Assyl, V. A. Georgiyants and L. O. Perekhoda Study of acyl substitution on docking properties of substituted dihydroquercetin as anti-inflammatory agents //Journal of Chemical and Pharmaceutical Research, 2014, 6 (4): 749-753.

[2] The State pharmacopoeia of the Republic of Kazakhstan. Issue 1. - Almaty: The publishing house "Zhibek Zholy", 2008. - P. 64-66.

[3] N. P. Sadchikova, A. P. Arzamastsev, A. V. Titova The method of near infrared spectroscopy in quality control of drugs (review) //Questions of Biological Medical and Pharmaceutical Chemistry. - 2010. - № 1. - P. 16-20.

[4] L. Bellamy Infrared spectra of complex molecules. - M.: Peace, 1983. - $432 \mathrm{p}$.

[5] B. N. Tarasevich Basics of IR spectroscopy with Fourier transform. Preparation of samples in the infrared spectroscopy. - M., 2012. - 22 p.

[6] A. I. Slivkin, O. V. Trineeva, E. E. Logvinova and other. Atlas IR spectra of drugs. - Voronezh: The Publishing and printing center of Voronezh State University, 2013. - 172 p.

[7] A. S. Krylov, A. A. Vtyurin, Y. V. Gerasimov Data Processing Fourier Transform Infrared Spectroscopy: manual. Krasnoyarsk Institute of Physics of the Russian Academy of Sciences, 2005. - 48 p.

[8] A. K. Boshkayeva, R. A. Omarova, M. K. Iskakova, A. M. Aktayeva, A. M. Toktabekova, M. R. Saurzhanova Evelopment and clinical laboratory researches of medicinal form "Maodent" //Actual Questions Of Development of New Drugs:Abstracts of XX International Scientific And Practical Conference Of Young Scientists And Student (April 2223,2014). - Kh.: Publishing Office, 2014. - P. 23-24.

[9] A. K. Boshkayeva, Z. B. Sakipova, A. G. Kenjebayeva Prediction of biological activity and determining the reactivity of derivatives dihydroquercetin // Vestnik of KazNMU, 2013. - № 5 (3). - P.36-38.

[10] A. K. Boshkayeva, H. M. Kamilov Application in the analysis of the reaction of formation of cyanine dyes // Pharmaceutical Journal. - Tashkent, 2009. - №2. - P. 55-59. 